\title{
Six-week treatment with hexarelin in young dogs: evaluation of the GH responsiveness to acute hexarelin or GHRH administration, and of the orexigenic effect of hexarelin
}

\author{
Antonello E Rigamonti, Silvano G Cella, Nicoletta Marazzi and Eugenio E Müller \\ Department of Medical Pharmacology, University of Milan, Milan, Italy \\ (Correspondence should be addressed to E E Müller, Department of Medical Pharmacology, University of Milan, Via Vanvitelli 32, 20129 Milan, \\ Italy; Email: eugenio.muller@unimi.it)
}

\begin{abstract}
In this study we evaluated, in six young (5-7 year-old) beagle dogs, the effects of a 6 -week administration of hexarelin $(250 \mu \mathrm{g} / \mathrm{kg}$ s.c. twice daily $)$ on the $\mathrm{GH}$ response to an acute challenge with hexarelin or GHRH ( $2 \mu \mathrm{g} / \mathrm{kg}$ i.v.), delivered before and after 3 and 6 weeks of treatment. The GH peak response to acute hexarelin or GHRH initially increased, with a maximum observed at the 3rd week, and then decreased to basal values (GHRH) or less (hexarelin) at the 6th week. These data would indicate that hexarelin initially primed the pituitary to acute administration of further hexarelin or of GHRH, followed by downregulation of the GH response to hexarelin and preservation of the response to GHRH. We then studied the rebound increase in GH secretion after withdrawal of an infusion of somatostatin $(4 \mu \mathrm{g} / \mathrm{kg}$ per $\mathrm{h}$ for $1.5 \mathrm{~h})$, a likely stimulus of endogenous GHRH function. The pattern obtained was similar to, though not superimposable upon, that ensuing after acute hexarelin or GHRH administration. Parallel evaluation of the acute orexigenic effect of hexarelin evinced a different timecourse of the behavioural response, namely an acute feeding response to hexarelin that was abolished at the 3rd week and returned to normal at the 6th week. The differing timing of the neuroendocrine or behavioural response to hexarelin would suggest the existence of different subtypes of central nervous system GH-releasing peptide receptors.
\end{abstract}

European Journal of Endocrinology 141 313-320

\section{Introduction}

In the past few years, the search for compounds as alternatives to either growth hormone $(\mathrm{GH})$ or $\mathrm{GH}-$ releasing hormone (GHRH) has resulted in the development of a new family of oligopeptides, named GH-releasing peptides (GHRPs) (1). This family now comprises a number of different short peptidyl and nonpeptidyl molecules, many of which have already proven to be effective in stimulating $\mathrm{GH}$ secretion in either animals $(2-4)$ or humans (5-9).

GHRPs exert other neuroendocrine and behavioural actions: though with different potency, they slightly activate the hypothalamic-pituitary-adrenal axis $(10-12)$ and also affect food intake (13-15) and sleep $(16,17)$. The intra- or extrahypothalamic mechanisms, or both, that underlie these central effects remain elusive.

In a previous study on the action of GHRP on somatotrophic function, we showed that, in aged dogs, a 16-week treatment with a high dosage of hexarelin, a hexapeptide analogue of these compounds, progressively potentiated the $\mathrm{GH}$ response to its own acute administration during the first month of treatment (18). However, evaluation of the GH response to acute hexarelin challenge at the 6th week of peptide administration revealed a decrease to $\mathrm{GH}$ values lower than those before treatment, though a washout interval of 2 weeks restored the original pattern of $\mathrm{GH}$ responsiveness to hexarelin (18). In that study, the potential ability of long-term treatment with hexarelin to interfere with GHRH function was not investigated, though it was likely that such an effect was occurring (19-21).

In this context, it is of note that we $(22,23)$ and others (24) have proposed the use of the rebound GH release that follows withdrawal of an infusion of somatostatin as a useful tool with which to evaluate endogenous GHRH function.

In our previous long-term study (18), the acute and chronic stimulation of GH release induced by hexarelin was apparently free from overt adverse effects. However, Clark and his colleagues (25) have raised the issue that the concomitant GH and cortisol release elicited by GHRPs may represent, in the long term, a diabetogenic stimulus with adverse effects on the use of GHRPs in the treatment of humans. 
In the present study, we examined the effects of a long-term treatment with hexarelin in young dogs, evaluating its impact on the acute response to GHRH and, though inferentially, the potential alterations induced by hexarelin in hypothalamic GHRH function. Finally, we evaluated parallel changes in cortisol concentrations and food intake.

\section{Materials and methods}

\section{Animals}

Experiments were performed in the dog, a species that behaves like humans for many aspects of $\mathrm{GH}$ regulation and presents with a GH secretory profile similar to that observed in humans $(2,18)$. Six young (ages $5-7$ years; weights $8-10 \mathrm{~kg}$; two male and four female), welltrained beagle dogs were used in this study. Animals were fed normal dry food (Diete Standard, Charles River, Calco, Italy) once a day, at $1600 \mathrm{~h}$, with water available ad libitum. The food not eaten was removed at $1900 \mathrm{~h}$, so that dogs were fasting until $0830 \mathrm{~h}$ of the experimental day (time of the first blood sampling), except in the experiments on food intake, which were performed at $1400 \mathrm{~h}$ (see below). Animals were subject to a regimen of $12 \mathrm{~h}$ light: $12 \mathrm{~h}$ darkness, with lights on at $0700 \mathrm{~h}$. Before and during the study, body weights of all dogs were stable and they had no observable disease.

All the experimental procedures were in accordance with that previously authorized by the Committee on Animal Care and Use of the University of Milan.

\section{Treatment schedule}

Hexarelin (Europeptides, Argenteuil, France) was administered twice daily at $0900 \mathrm{~h}$ and $1700 \mathrm{~h}$, in a dose of $250 \mu \mathrm{g} / \mathrm{kg}$ s.c. The entire treatment period lasted 6 weeks.

Once in a week, $5 \mathrm{ml}$ blood were drawn from the cephalic vein in all dogs, at $0830 \mathrm{~h}$, for the determinations of insulin-like growth factor (IGF)-I and cortisol.

The different experiments - acute hexarelin or GHRH testing, infusion of somatostatin, and food intake (see below) - were performed in a randomized sequence, with 24-h intervals, starting before hexarelin treatment or at the end of the 3rd or 6th week of hexarelin treatment.

\section{Acute hexarelin testing}

After one baseline blood sample had been taken $(-30 \mathrm{~min})$, dogs received hexarelin $(250 \mu \mathrm{g} / \mathrm{kg}$ i.v. $)$ at time 0 and then samples were obtained at 15,30, 45, 60 and 90 min post-injection.

\section{Acute GHRH testing}

Dogs were challenged with the administration of GHRH $\left(2 \mu \mathrm{g} / \mathrm{kg}\right.$ i.v.; GRF(1-29)- $\mathrm{NH}_{2}$, Pharmacia \& Upjohn,
Milan, Italy). Blood samples were taken at $-30,0$ (the time of GHRH injection) and at 15, 30, 45, 60 and 90 min post-injection.

\section{Somatostatin infusion}

An indwelling, non-thrombogenic i.v. catheter was positioned and maintained in the cephalic vein for the duration of each individual experiment. A solution of $0.9 \%$ saline was delivered $(5 \mathrm{ml} / \mathrm{h})$ for $30 \mathrm{~min}$, after which an i.v. infusion of $4 \mu \mathrm{g} / \mathrm{kg}$ per h somatostatin $(5 \mathrm{ml} / \mathrm{h}$; Stilamin, Serono, Milan, Italy) was delivered for $1.5 \mathrm{~h}$. The infusion of somatostatin was then stopped and $0.9 \%$ saline $(5 \mathrm{ml} / \mathrm{h})$ was again infused for $1.5 \mathrm{~h}$.

Blood samples were drawn 30 min before the somatostatin infusion, at $0 \mathrm{~min}$ (the time of starting the somatostatin infusion), at 30-min intervals during the somatostatin infusion, and 15-30 min after withdrawal of the somatostatin infusion.

The extent of the GH response at the termination of the somatostatin infusion was taken to reflect the endogenous GHRH function (22-24).

\section{Evaluation of food intake}

The dogs were given, in a large cup, a premeasured quantity of their normal food $(30 \mathrm{~g} / \mathrm{kg})$ at $1400 \mathrm{~h}$. The test meal (time 0 ) was offered 5 min after administration of hexarelin $(250 \mu \mathrm{g} / \mathrm{kg}$ s.c.) or saline $(0.1 \mathrm{ml} / \mathrm{kg}$ s.c. $)$ (time $-5 \mathrm{~min}$ ). Each cup, with its remaining content of food, was carefully weighed, to the nearest $0.1 \mathrm{~g}$, at 0,5 , $10,20,30,60,90,120$ and $150 \mathrm{~min}$ after the test meal. After each measurement of the food eaten, the remaining food was quickly made available to the dog again.

\section{Sample determinations}

All blood samples were collected in chilled tubes containing 400 kallikrein inhibitor units of aprotinin (Sigma Tau, Milan, Italy) and $1.2 \mathrm{mg}$ EDTA $/ \mathrm{ml}$ blood and centrifuged. The plasma was then frozen at $-80^{\circ} \mathrm{C}$ until required for assay.

\section{GH radioimmunoassay}

Highly purified canine GH, used for iodination and as a standard, and monkey anti-canine $\mathrm{GH}$ antiserum were obtained through the courtesy of Dr A F Parlow (Pituitary Hormones and Antisera Center, Torrance, CA, USA). The sensitivity of the assay was $0.4 \mathrm{ng} / \mathrm{ml}$. The intra-assay coefficients of variation were 3.8 and $4.1 \%$ at concentrations of 12.5 and $3.1 \mathrm{ng} / \mathrm{ml}$ respectively. To avoid possible interassay variation, all samples of a given experiment were assayed in a single RIA. 


\section{IGF-I concentrations}

Serum concentrations of IGF-I were determined by RIA of acid-extracted samples (26). Serum was mixed $1: 1$ with acetic acid $2 \mathrm{~mol} / \mathrm{l}$ and incubated for $1 \mathrm{~h}$ at room temperature. The incubation mixture $(200 \mu \mathrm{l})$ was applied to a Sephadex G-50 column $(0.9 \times 28 \mathrm{~cm})$ and eluted with acetic acid $1 \mathrm{~mol} / \mathrm{l}$ and $\mathrm{NaCl} 0.02 \mathrm{~mol} / \mathrm{l}$ at a flow rate of $5 \mathrm{ml} / \mathrm{h}$. The IGF-I fraction, which eluted at $K_{\mathrm{d}}$ values between 0.37 and 0.75 , was lyophilized and assayed by a homologous RIA with reagents provided by Amersham, Milan, Italy. The recovery from gel filtration was $90 \%$. The sensitivity of the assay was $0.1 \mathrm{ng} / \mathrm{ml}$; intra- and interassay variations were less than $10 \%$.

\section{Cortisol concentrations}

Plasma concentrations of cortisol were determined by RIA provided by ICN, Milan, Italy.

\section{Statistical analysis}

GH was evaluated either as absolute mean values $(\mathrm{ng} / \mathrm{ml}) \pm$ s.E.M. or as area under the $\mathrm{GH}$ response curve $\left(\mathrm{AUC}_{\mathrm{O}-90} \mathrm{~min} ; \mathrm{ng} / \mathrm{ml}\right.$ per $\left.\mathrm{h}\right)$, calculated by the trapezoid method. IGF-I $(\mathrm{ng} / \mathrm{ml})$ and cortisol $(\mu \mathrm{g} / \mathrm{dl})$ were expressed as absolute mean values \pm s.E.M. Food intake was expressed as a percentage of the food ingested at the test meal after hexarelin or saline administration, with subsequent cumulative values.

No differences in analytical levels between male and female dogs were observed in the different experimental conditions, therefore these data were pooled.

Statistical comparisons of the mean values were performed by Student's $t$-test for unpaired or (where necessary) paired data, preceded by ANOVA; $\mathrm{P} \leq 0.05$ was taken to be statistically significant.

\section{Results}

\section{Acute hexarelin testing}

Baseline GH values before hexarelin or after the 3rd and 6 th weeks of hexarelin treatment did not differ significantly (time $0 \mathrm{~min}: 0.5 \pm 0.1,0.5 \pm 0.2,0.6 \pm$ $0.1 \mathrm{ng} / \mathrm{ml}$, respectively; $P=\mathrm{NS}$ ) (Fig. 1 ). There was, however, a striking change in the $\mathrm{GH}$ responsiveness to the acute hexarelin challenge: the means of individual $\mathrm{GH}$ peak responses were $79.9 \pm 18.0 \mathrm{ng} / \mathrm{ml}$ before hexarelin treatment, $168.3 \pm 12.8 \mathrm{ng} / \mathrm{ml}$ after the $3 \mathrm{rd}$ week and $37.0 \pm 26.8 \mathrm{ng} / \mathrm{ml}$ after the 6 th week of treatment (Fig. 1). In all dogs, plasma GH concentrations peaked between 15 and 30 min post-injection, and remained increased at $60 \mathrm{~min}$.

Determinations of the $\mathrm{AUC}_{0-90}$ values showed that the $\mathrm{GH}$ response to the peptide challenge increased significantly after the 3rd week of treatment (from

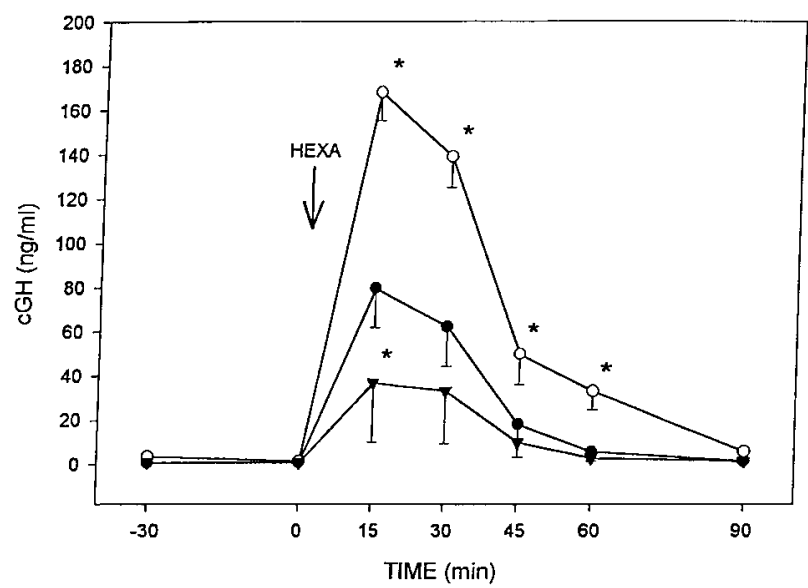

Figure $1 \mathrm{GH}$ responses after an acute challenge with hexarelin $(250 \mu \mathrm{g} / \mathrm{kg}$ i.v.) in six beagle dogs treated for 6 weeks with hexarelin in a daily dose of $250 \mu \mathrm{g} / \mathrm{kg}$ s.c. three times a day, before hexarelin (0) or at the end of the 3rd $(\bigcirc)$ or 6th $(\boldsymbol{\nabla})$ week of hexarelin treatment. Means \pm S.E.M. of six determinations made in duplicate. ${ }^{\star} P<0.01$ compared with baseline.

$2574.8 \pm 649.5$ to $6211.2 \pm 599.0 \mathrm{ng} / \mathrm{ml}$ per $\mathrm{h}, P<$ 0.01 ), but, after the 6 th week, decreased to values less than those present before treatment (1308.4 \pm $903.9 \mathrm{ng} / \mathrm{ml}$ per h, $P<0.01$ ) (Fig. 2).

\section{Acute GHRH testing}

Baseline GH values before hexarelin or after the 3rd and 6th weeks of hexarelin treatment did not differ significantly (time $0 \mathrm{~min}: 0.5 \pm 0.1,0.5 \pm 0.0,0.6 \pm$ $0.1 \mathrm{ng} / \mathrm{ml}$, respectively; $P=$ not significant) (Fig. 3). The mean $\mathrm{GH}$ peak responses to the acute $\mathrm{GHRH}$ challenge were $2.1 \pm 0.9 \mathrm{ng} / \mathrm{ml}$ before hexarelin treatment $(P<0.01$ compared with baseline), $12.3 \pm 3.2 \mathrm{ng} / \mathrm{ml}$ after the 3 rd week and $2.8 \pm 1.1 \mathrm{ng} / \mathrm{ml}$ after the 6 th week of treatment $(P<0.01$ compared with baseline $)$ (Fig. 3). In all dogs, the GH peak value was reached between 15 and $30 \mathrm{~min}$ after GHRH injection, and plasma $\mathrm{GH}$ concentrations remained increased at $60 \mathrm{~min}$.

Hexarelin treatment induced, after the 3rd week, a significant increase in the GH responses to GHRH $\left(\mathrm{AUC}_{0-90}\right.$ increased from $111.1 \pm 31.1 \mathrm{ng} / \mathrm{ml}$ per $\mathrm{h}$ to $361.9 \pm 87.7 \mathrm{ng} / \mathrm{ml}$ per h, $P<0.01$ ), but, after the 6 th week, the GH responses to GHRH had declined to become almost superimposable on those present before hexarelin treatment $\left(\mathrm{AUC}_{0-90} 137.0 \pm 38.9 \mathrm{ng} / \mathrm{ml}\right.$ per $\left.\mathrm{h}, P=\mathrm{NS}\right)$ (Fig. 2).

\section{Somatostatin infusion}

Baseline GH values before hexarelin or after the 3rd and 6 th weeks of hexarelin treatment did not differ significantly (time $0 \mathrm{~min}: 0.5 \pm 0.1,0.6 \pm 0.1,0.5 \pm$ $0.1 \mathrm{ng} / \mathrm{ml}$, respectively; $P=\mathrm{NS}$ ) (Fig. 4). Before hexarelin 


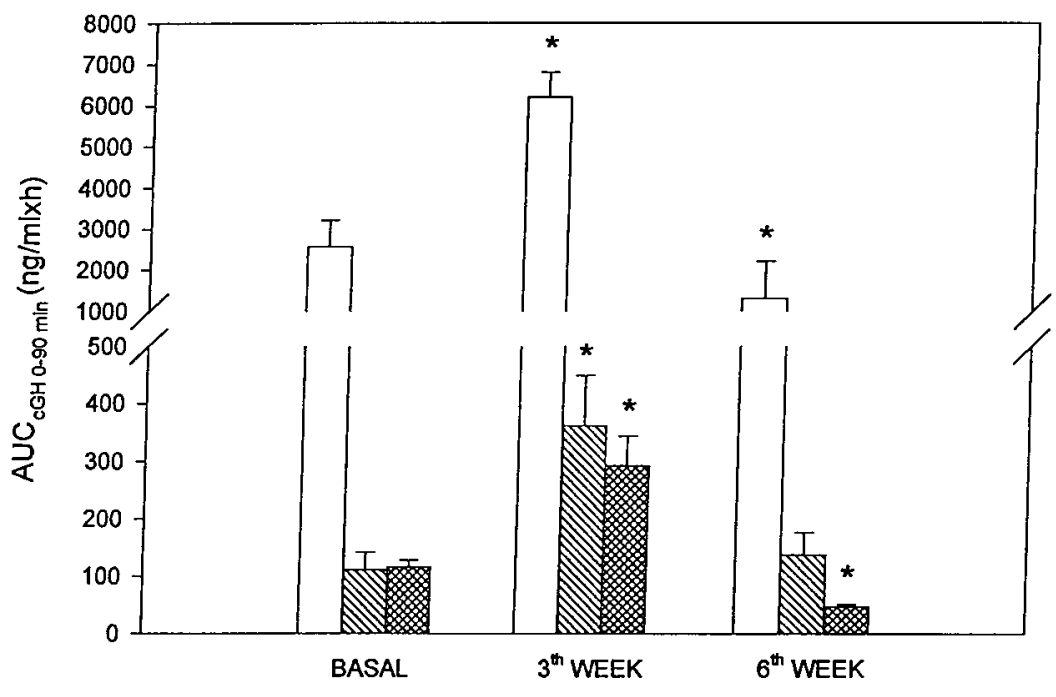

$\square$ HEXA $(250 \mu g / k g, i v)$ GHRH $(2 \mu \mathrm{g} / \mathrm{kg}, \mathrm{iv})$

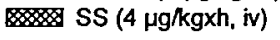

Figure 2 Areas under the curve ( 0 and $90 \mathrm{~min})$ of the $\mathrm{GH}$ responses after an acute challenge with hexarelin (HEXA) or GHRH and of the rebound increase in $\mathrm{GH}$ after the withdrawal of somatostatin (SS) infusion in six beagle dogs, before hexarelin or at the end of the 3rd or 6th week of hexarelin treatment. Means \pm S.E.M. of six determinations made in duplicate. ${ }^{\star} P<0.01$ compared with baseline. treatment, termination of the somatostatin infusion was followed by a small, but unequivocal, increase in plasma GH (mean GH peaks: $3.4 \pm 0.8 \mathrm{ng} / \mathrm{ml}$; $\mathrm{AUC}_{0-90}$ $106.2 \pm 12.3 \mathrm{ng} / \mathrm{ml}$ perh) (Figs 2, 4). After the 3rd week of treatment, there was a consistent enhancement of the increase in GH that occurred after withdrawal of somatostatin (mean GH peaks: $7.1 \pm 1.9 \mathrm{ng} / \mathrm{ml}, P<$ $0.01 ; \mathrm{AUC}_{0-90} 283.8 \pm 51.1 \mathrm{ng} / \mathrm{ml}$ per $\left.\mathrm{h} ; P<0.01\right)$ (Figs 2, 4), but no increase in $\mathrm{GH}$ occurred after

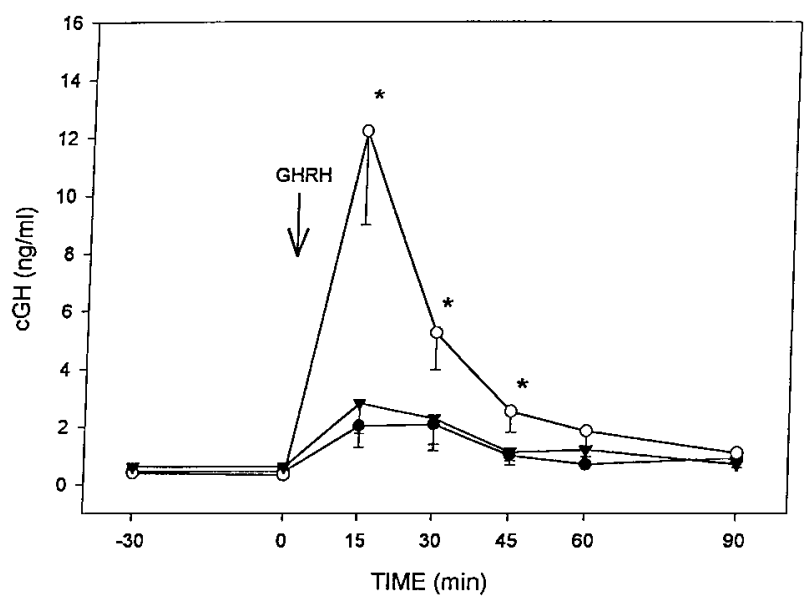

Figure $3 \mathrm{GH}$ responses after an acute challenge with GHRH $(2 \mu \mathrm{g} /$ $\mathrm{kg}$ i.v.) in six beagle dogs treated for 6 weeks with hexarelin in a daily dose of $250 \mu \mathrm{g} / \mathrm{kg}$ s.c. three times a day, before hexarelin ( or at the end of the 3rd $(O)$ or 6 th $(\mathbf{\nabla})$ week of hexarelin treatment. Means \pm S.E.M. of six determinations made in duplicate. ${ }^{*} P<0.01$ compared with baseline. termination of the somatostatin infusion at the 6th week of treatment (mean GH peaks: $0.8 \pm 0.0 \mathrm{ng} / \mathrm{ml}$; $\mathrm{AUC}_{0-90} 39.4 \pm 2.9 \mathrm{ng} / \mathrm{ml}$ per h compared with before hexarelin treatment; $P<0.01$ ) (Figs 2, 4).

\section{Serum IGF-I concentrations}

During treatment, serum concentrations of IGF-I did not change significantly from pretreatment (data not shown).

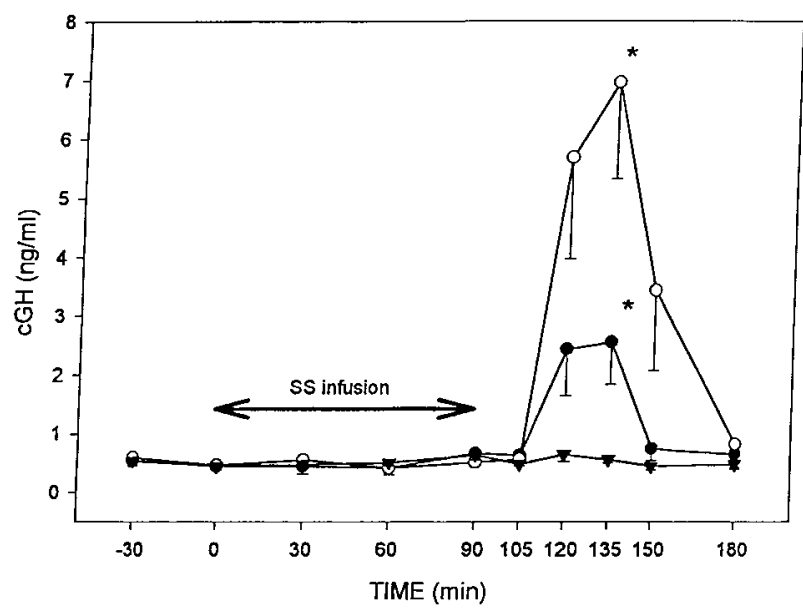

Figure 4 Rebound increase in GH concentration after withdrawal of the infusion of somatostatin $(4 \mu \mathrm{g} / \mathrm{kg} \mathrm{perh})$ in six beagle dogs treated for 6 weeks with hexarelin in a daily dose of $250 \mu \mathrm{g} / \mathrm{kg} \mathrm{s.c.}$ three times a day, before hexarelin $(\bullet)$ or at the end of the 3rd (O) or 6 th $(\mathbf{\nabla})$ week of hexarelin treatment. Means \pm S.E.M. of six determinations made in duplicate. ${ }^{*} P<0.01$ compared with baseline. 


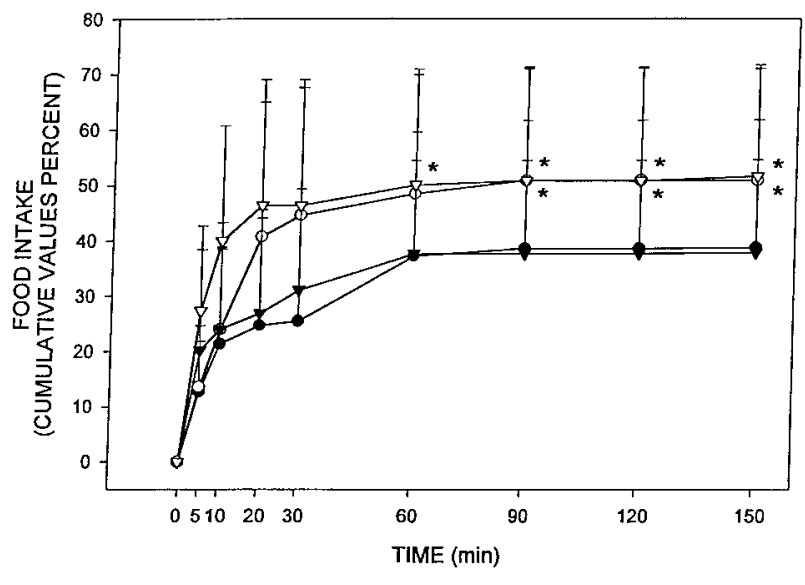

Figure 5 Food intake in six dogs after administration of hexarelin $(250 \mu \mathrm{g} / \mathrm{kg} \mathrm{s.c.)}$ or saline $(0.1 \mathrm{ml} / \mathrm{kg} \mathrm{s.c.)}$. Food intake measurements were performed before hexarelin ( $\bullet$, saline; $\bigcirc$, hexarelin) or at the end of the $\operatorname{3rd}(\mathbf{\nabla})$ or 6 th $(\nabla)$ week of hexarelin treatment. Means \pm S.E.M. ${ }^{*} P<0.01$ compared with baseline.

\section{Food intake}

During the pretreatment phase, acute administration of hexarelin increased food intake, an effect first evident at $60 \mathrm{~min}$. The cumulative amounts of food eaten by dogs at $60,90,120$ and 150 min corresponded respectively to $37.4 \pm 22.3 \%, 38.7 \pm 23.0 \%, 38.8 \pm 23.0 \%$ and $38.9 \pm 23.0 \%$ of the preweighed quantity after saline injection and to $48.6 \pm 21.3 \%, 51.0 \pm 20.0 \%, 51.0 \pm$ $20.1 \%$ and $51.0 \pm 20.1 \%$ after hexarelin injection $(P<0.01)$ (Fig. 5). At the 3rd week, the stimulatory effect on food intake was not evident, the cumulative amounts of test meal eaten by dogs now being superimposable on those eaten after saline administration (Fig. 5). At the 6th week of treatment, the pattern of the eating response after acute administration of hexarelin became superimposable on that elicited by the peptide before treatment (Fig. 5).

\section{Cortisol concentrations}

Pretreatment plasma cortisol concentrations were $0.6 \pm 0.1 \mu \mathrm{g} / \mathrm{dl}$. They were unaltered at the $1 \mathrm{st}$ and $2 \mathrm{nd}$ weeks of treatment $(0.7 \pm 0.2 \mu \mathrm{g} / \mathrm{dl}$ and $0.6 \pm 0.1 \mu \mathrm{g} / \mathrm{dl}$, respectively; $P=$ NS). Plasma cortisol titres then progressively decreased, reaching nadir values at the $3 \mathrm{rd}$ and 6th weeks $(0.4 \pm 0.0 \mu \mathrm{g} / \mathrm{dl}$ and $0.3 \pm 0.0 \mu \mathrm{g} / \mathrm{dl} \mathrm{respec-}$ tively; $P<0.01$ compared with pretreatment) (data not shown).

\section{Adverse effects}

There were no signs of discomfort or overt adverse reactions after acute or repeated peptide treatment.

\section{Discussion}

We have previously shown that in old dogs exposed chronically to high doses of hexarelin, the peptide restores the GH secretory profile to normal (18). In this study, although we did not examine the GH secretory profiles, we demonstrated that, in young dogs, hexarelin is a very effective $\mathrm{GH}$ releaser that primes the pituitary to its own GH-releasing effect during the first 3 weeks of treatment. At the 6th week, however, these effects had subsided. In keeping with all our data in dogs (this study and (18)), Rahim et al. (27) showed that, in healthy elderly subjects, during the course of a 16-week treatment with hexarelin there was, at the 4 th week of treatment, a decline in the GH response to an acute hexarelin challenge, which had returned to normal 4 weeks after completion of the peptide therapy.

We are currently unable to identify precisely either the site(s) or the mechanism(s) responsible for the blunting of the $\mathrm{GH}$ response to the peptide - that is, whether it occurred directly at GHRP receptors located on GHRH neurones in the arcuate or ventromedial nuclei of the hypothalamus $(21,28,29)$ or, alternatively, at central nervous system (CNS) or pituitary GHRP receptors downregulated by increased circulating $\mathrm{GH}$ titres $(30,31)$. In this context, involvement of the feedback inhibitory action of circulating IGF-I $(32,33)$ is unlikely, as plasma IGF-I titres did not change significantly under treatment and, conversely, in the study by Lieber et al. (34), the GH response to L-163,255, a non-peptidyl GHRP mimetic, did not subside in dogs treated for 15 weeks, despite the increase in circulating $\mathrm{GH}$ and IGF-I concentrations. An enhanced hexarelin-induced production of tissue IGF-I and a paracrine/autocrine action at the hypothalamopituitary system cannot, however, be ruled out in our study (18).

Whichever the cause of the rather delayed decline of the $\mathrm{GH}$ responsiveness to hexarelin, this phase was preceded, in the first 3 weeks of treatment, by a striking increase in the $\mathrm{GH}$ responsiveness to the peptide. A similar pattern had been demonstrated in the early phases of hexarelin administration in old dogs, in which, however, even during the off-periods of the peptide treatment, baseline $\mathrm{GH}$ concentrations remained higher than pretreatment values (18). In infant GHRH-deprived rats, treatment with hexarelin for 3 or 5 days increased pituitary GH mRNA (35), whereas, given for 5-10 days to young 'intact' adult rats, it was ineffective in this context (36). Also worth noting in this context is that, in young GHRH-deprived rats, a 10-day treatment with hexarelin increased the expression of its own receptors in the pituitary (R Nass \& A Torsello, unpublished results). In our present study, baseline GH concentrations were not different at the three periods of hexarelin challenge, which would indicate that the ability of GHRP to prime the pituitary was confined to $\mathrm{GH}$ release, and did not involve GH synthesis. 
The enhanced GH responsiveness to hexarelin, present in both rats (35) and dogs (this study and (18)) during the initial phase of treatment has not been reported previously in humans $(27,37,38)$. Although difficult to interpret, this discrepancy may be due to the higher sensitivity of humans than rats and dogs to the GH-releasing activity of the GHRPs, an event for which no clear explanation is available at present. Peptide doses two orders of magnitude lower than those used in our study are active in humans, inducing a robust release of $\mathrm{GH}(2,8,39)$. Thus, in humans, the potential ability of hexarelin to prime the pituitary may be obscured by the occurrence of early receptor or post-receptor changes $(27,40)$.

Parallel evaluation of the $\mathrm{GH}$ response to an acute GHRH challenge during the course of treatment revealed its enhancement at the 3rd week, an event temporally fitting well with the increased response to the acute hexarelin challenge. At the 6th week, the GH response to GHRH was attenuated, but was still comparable to that induced by GHRH at pretreatment. Similar, but not superimposable, results were obtained in our study by evaluating, albeit inferentially, hypothalamic GHRH neurones freed from the inhibitory influences of somatostatin (22-24). Following somatostatin infusion, the rebound increase in GH was enhanced at the 3rd week, but completely abolished at the 6th week. This finding is of particular interest when viewed in relation to the preserved $\mathrm{GH}$ response to GHRH at this time. These observations would suggest that a sustained treatment with hexarelin desensitized the hypothalamic GHRH mechanism(s), but preserved the pituitary competence to respond to CNS-driven stimuli. As an alternative possibility, chronic administration of the peptide might have decreased a putative endogenous hypothalamic non-GHRH ligand (U factor), involved in GHRP stimulatory effects (1). A note of caution in interpreting these findings is necessary, however, as, in dogs under baseline conditions, the pituitary responsiveness to the heterologous GHRH is poor (authors' unpublished results, and this study), so that differences encountered at the different time periods were not so clear cut.

Further support for the view that the tolerance following sustained hexarelin treatment is a centrallymediated event was provided by the results regarding food intake, a behavioural function mainly driven by the CNS $(41,42)$. Before treatment, the acute hexarelin challenge induced a clear-cut, though transient, increase in food intake, thus for the first time extending to dogs previous findings obtained with GHRPs in rats $(13-15)$. In the present study, however, the temporal pattern of the behavioural response was divorced from that of the neuroendocrine response: the feeding response was not enhanced at the 3rd week and, unexpectedly, had returned to the original response by the 6th week of treatment. We do not know, at present, the underlying cause of this temporal pattern; however, it supports the proposition of the existence of different receptor subtypes engaged in the manyfold actions of GHRPs (43-45). There are now peptidyl mimetics of GHRPs that stimulate food intake and lack neuroendocrine effects, and vice versa (15).

Studies in both animals (10) and humans (12) have reported the ability of hexarelin, acutely administered, to increase plasma ACTH and cortisol concentrations. In our study, however, plasma cortisol concentrations were unaltered during the early phase and were reduced during the late phase of treatment. Reduction of cortisol concentrations recalls the occurrence of tolerance of the GHRP stimulatory effect on the hypothalamo-pituitary-adrenal axis (11), although an initial stimulatory phase in our study was lacking.

In all, these data indicate that a 6-week hexarelin treatment initially primes the pituitary to its own acute administration and to acute administration of GHRH. This is followed by downregulation of the GH response to hexarelin and preservation of the $\mathrm{GH}$ response to GHRH. It would seem, therefore, that GHRH can be helpful in triggering GH release from a pituitary made unresponsive to hexarelin.

The orexigenic response to hexarelin has a temporal pattern that is distinct from that of the neuroendocrine response, implying the existence of different subtypes of GHRP receptors and the potential for their therapeutic exploitation. Obviously, the use of other GHRP agonists - for example MK $677(9,11)$ - would be of aid in establishing the existence of distinct GHRP receptor subtypes.

\section{References}

1 Locatelli V \& Torsello A. Growth hormone secretagogues: focus on the growth hormone-releasing peptides. Pharmacological Research $199736415-423$.

2 Cella SG, Locatelli V, Poratelli M, De Gennaro Colonna V, Imbimbo BP, Deghenghi R et al. HEXA, a potent GHRP analogue: interactions with GHRH and clonidine in young and aged dogs. Peptides 1995 $1681-86$.

3 Deghenghi R, Boutignon F, Luoni M, Grilli R, Guidi M \& Locatelli V. Small peptides as potent releasers of growth hormone. Journal of Pediatric Endocrinology and Metabolism 19958 311-313.

4 Smith RG, Cheng K, Schoen WR, Pong S-S, Hickey G, Jacks T et al. A non-peptidyl growth hormone secretagogue. Science 1993260 1640-1643.

5 Ilson BE, Jorkasky DK, Curnow RT \& Stote RM. Effect of a new synthetic hexapeptide to selectively stimulate growth hormone release in healthy human subjects. Journal of Clinical Endocrinology and Metabolism 198969 212-214.

6 Bowers CY, Reynolds GA, Durham D, Barrera CM, Pezzoli SS \& Thorner MO. Growth hormone (GH)-releasing peptide stimulates $\mathrm{GH}$ release in normal men and acts synergistically with GHreleasing hormone. Journal of Clinical Endocrinology and Metabolism 199070 975-982.

7 Gertz BJ, Barrett JS, Eisenhandler R, Krupa DA, Wittreich JM, Seibold JR et al. Growth hormone response in man to L-692,429, a novel nonpeptide mimic of growth hormone releasing peptide- 6 . Journal of Clinical Endocrinology and Metabolism 199377 13931397.

8 Arvat E, Gianotti L, Di Vito L, Imbimbo BP, Lenaerts V, Deghenghi $\mathrm{R}$ et al. Modulation of growth hormone-releasing activity of HEXA in man. Neuroendocrinology 199561 51-56. 
9 Chapman IM, Bach MA, van Cauter E, Farmer M, Krupa D, Taylor AM et al. Stimulation of the growth hormone (GH)-insulin-like growth factor axis by daily oral administration of a $\mathrm{GH}$ secretagogue (MK-677) in healthy elderly subjects. Journal of Clinical Endocrinology and Metabolism 1996 81 4249-4257.

10 Jacks T, Hickey G \& Judith F. Effects of acute and repeated intravenous administration of L-692,585, a novel non-peptidy growth hormone secretagogue, on plasma growth hormone, IGF-I, ACTH, cortisol, prolactin, insulin, and thyroxine levels in beagles. Journal of Endocrinology 1994143 399-406.

11 Copinschi G, van Onderbergen A, l'Hermite-Baleriaux M, Mendel CM, Caufriez A, Leproult R et al. Effects of a 7-day treatment with a novel, orally active, growth hormone (GH) secretagogue, MK-677, on 24-h GH profiles, insulin-like growth factor I, and adrenocortica function in normal young men. Journal of Clinical Endocrinology and Metabolism 199681 2776-2782.

12 Arvat E, Maccagno B, Ramunni J, Di Vito L, Broglio F, Deghenghi $\mathrm{R}$ et al. Hexarelin, a synthetic growth-hormone releasing peptide, shows no interaction with corticotropin-releasing hormone and vasopressin on adrenocorticotropin and cortisol secretion in humans. Neuroendocrinology 199766 432-438.

13 Locke W, Kirgis HD, Bowers CY \& Abdoh AA. Intracerebroventricular growth hormone-releasing peptide-6 stimulates eating without affecting plasma growth hormone responses in rats. Life Science $1995561347-1352$.

14 Okada K, Ishii S, Minami S, Shibasaki T \& Wakabayashi I. Intracerebroventricular administration of the growth hormonereleasing peptide KP-102 increases food intake in free-feeding rats. Endocrinology $19961375155-5158$.

15 Torsello A, Luoni M, Schweiger F, Grilli R, Guidi M, Bresciani E et al. Novel hexarelin analogs stimulate feeding in the rat through a mechanism not involving growth hormone release. European Journal of Pharmacology 1998360 123-129.

16 Frieboes RM, Murck H, Maier P, Schier T, Holsboer F \& Steiger A. Growth hormone-releasing peptide-6 stimulates sleep, growth hormone, ACTH and cortisol release in normal man. Neuroendocrinology $199561584-589$.

17 Moreno Reyes R, Kerkhofs M, l'Hermite Baleriaux M, Thorner MO, Van Cauter E \& Copinschi G. Evidence against a role for the growth hormone-releasing peptide axis in human slow-wave sleep regulation. American Journal of Physiology 1998274 E779E784.

18 Cella SG, Cerri CG, Daniel S, Sibilia V, Rigamonti A, Cattaneo L et al. Sixteen weeks of hexarelin therapy in aged dogs: effect on the somatotropic axis, muscle morphology, and bone metabolism. Journal of Gerontology 1996 51A B439-B447.

19 Clark RG, Carlsson LMS, Trojnar J \& Robinson ICAF. The effects of a growth hormone-releasing peptide and growth hormonereleasing factor in conscious and anaesthetized rats. Journal of Neuroendocrinology $19891249-255$.

20 Guillaume V, Magnan E, Cataldi M, Dutour A, Sauze N, Renard M et al. GH-releasing hormone secretion is stimulated by a new GH-releasing hexapeptide in sheep. Endocrinology 1994135 1073-1076.

21 Dickson SL, Leng G, Dyball REJ \& Smith RG. Central action of peptide and non-peptide growth hormone secretagogues in the rat. Neuroendocrinology $19956136-43$.

22 Cella SG, Luceri M, Cattaneo L \& Müller EE. Somatostatin withdrawal as generator of pulsatile $\mathrm{GH}$ release in the dog: a possible tool to evaluate the endogenous GHRH tone? Neuroendocrinology $199663481-488$.

23 Degli Uberti EC, Ambrosio MR, Cella SG, Margutti AR, Trasforin G, Rigamonti AE et al. Defective hypothalamic growth hormone (GH)-releasing hormone activity may contribute to declining $\mathrm{GH}$ secretion with age in man. Journal of Clinical Endocrinology and Metabolism 199782 2885-2888.

24 Magnan E, Cataldi M, Guillaume V, Conte-Devolx B, Graziani N, Figaroli JC et al. Acute changes in growth hormone-releasing hormone secretion after injection of BIM 23014, a long acting somatostatin analog, in rams. Life Science $199251831-838$.
25 Clark RG, Thomas GB, Mortensen DL, Won WB, Ma YH, Tomlinson EE et al. Growth hormone secretagogues stimulate the hypothalamic-pituitary-adrenal axis and are diabetogenic in the Zucker diabetic fatty rat. Endocrinology $19971384316-$ 4323.

26 Daugaday WH, Kapadia M \& Mariz I. Serum somatomedin binding proteins: physiologic significance and interference in radioligand assay. Journal of Laboratory and Clinical Medicine 1987 $109355-363$.

27 Rahim A, O'Neill PA \& Shalet SM. Growth hormone status during long-term hexarelin therapy. Journal of Clinical Endocrinology and Metabolism 199883 1644-1649.

28 Argente J, Garcia-Segura LM, Pozo J \& Chowen JA. Growth hormone-releasing peptides: clinical and basic aspects. Hormone Research 199646 155-159.

29 Dickson S, Macdonald LP, Bailey ART \& Leng G. Retrograde labelling of GHRP-6-responsive cells in the rat arcuate nucleus which project to the paraventricular nucleus (PVN) of the hypothalamus. In Book of Abstracts of the 80th Annual Meeting of the Endocrine Society, June 24-27 1998, New Orleans. Abstract OR09-5, p. 64.

30 Arvat E, Di Vito L, Gianotti L, Ramunni J, Boghen M, Deghenghi R et al. Mechanisms underlying the negative growth hormone (GH) autofeedback on the GH-releasing effect of hexarelin in man. Metabolism 199746 83-88.

31 Bennett PA, Thomas GB, Howard AD, Feighner SD, van der Ploeg LH, Smith RG et al. Hypothalamic growth hormone secretagogue-receptor (GHS-R) expression is regulated by growth hormone in the rat. Endocrinology $19971384552-$ 4557.

32 Berelowitz M, Szabo LA, Firestone S, Chu L \& Hintz RL. Somatomedin $\mathrm{C}$ mediates growth hormone negative feedback by effects on both the hypothalamus and the pituitary. Science 1981 212 1279-1281.

33 Ceda GP. IGFs in the feedback control of GH secretion: hypothalamic and/or pituitary action? Journal of Endocrinological Investigation 199518 734-737.

34 Lieber RL, Jacks TM, Mohler RL, Schleim K, Haven M, Cuizon D et al. Growth hormone secretagogue increases muscle strength during remobilization after canine hindlimb immobilization. Journal of Orthopaedic Research 199715 519-527.

35 Locatelli V, Grilli R, Torsello A, Cella SG, Wehrenberg WB \& Müller EE. Growth hormone releasing hexapeptide is a potent stimulator of growth hormone gene expression and release in the growth hormone-releasing hormone-deprived infant rat. Pediatric Research 199436 169-174.

36 Torsello A, Luoni M, Grilli R, Guidi M, Wehrenberg WB, Deghenghi $\mathrm{R}$ et al. Hexarelin stimulation of growth hormone release and mRNA levels in an infant and adult rat model of impaired GHRH function. Neuroendocrinology 199765 91-97.

37 Klinger B, Silbergeld A, Deghenghi R, Frenkel J \& Laron Z. Desensitization from long term intranasal treatment with hexarelin does not interfere with the biological effects of this growth hormone-releasing peptide in short children. European Journal of Endocrinology 1996134 716-719.

38 Ghigo E, Arvat E, Gianotti L, Grottoli S, Rizzi G, Ceda GP et al. Short-term administration of intranasal or oral hexarelin, a synthetic hexapeptide, does not desensitize the growth hormone responsiveness in human aging. European Journal of Endocrinology $1996135407-412$.

39 Ghigo E, Arvat E, Gianotti L, Imbimbo BP, Lenaerts V, Deghenghi $\mathrm{R}$ et al. Growth hormone-releasing activity of hexarelin, a new synthetic hexapeptide, after intravenous, subcutaneous, intranasal, and oral administration in man. Journal of Clinical Endocrinology and Metabolism 199478 693-698.

40 Bennett PA, Thomas GB \& Robinson ICAF. Growth hormonereleasing peptide (GHRP-6) regulation of hypothalamic gene expression. In Book of Abstracts of the 80th Annual Meeting of the Endocrine Society, June 24-27 1998, New Orleans. Abstract P2225, p. 299. 
41 Morley JE. Neuropeptide regulation of appetite and weight. Endocrine Review 19878 256-287.

42 Inui A, Okita M, Nakajima M, Inoue T, Sakatani N, Oya M et al. Neuropeptide regulation of feeding in dogs. American Journal of Physiology 1991261 R588-R594.

43 Hansen BS, Hansen A, Vissing H \& Andersen PH. Growth hormone secretagogue receptor subtypes? In Book of Abstracts of the 80th Annual Meeting of the Endocrine Society, June 24-27 1998, New Orleans. Abstract P2-220, p. 298.

44 Muccioli G, Ghe C, Ghigo MC, Papotti M, Arvat E, Boghen M et al. Specific receptors for synthetic $\mathrm{GH}$ secretagogues in the human brain and pituitary gland. Journal of Endocrinology $199815799-$ 106.

45 Ong H, McNicoll N, Escher E, Collu R, Deghenghi R, Locatelli V et al. Identification of a pituitary growth hormone-releasing peptide (GHRP) receptor subtype by photoaffinity labeling. Endocrinology $1998139432-435$.

Received 1 March 1999

Accepted 31 May 1999 